\title{
DETECTION OF GENETIC DIVERSITY IN AN ORNAMENTAL MOLLIES FISH VARIETY (Poecilia species) USING RAPD MOLECULAR MARKERS
}

\author{
PRASAD M.P.*, CHIKKASWAMY B.K. AND SHEKHAR S. \\ Sangenomics Research Lab, Address- \#16, 2nd Cross, Krishna Reddy Colony, Domlur Layout, Airport Road, Bangalore- 560071, Karnataka, \\ India. \\ *Corresponding Author: Email- prasad_m_p@hotmail.com
}

Received: January 03, 2012; Accepted: February 07, 2013

\begin{abstract}
Successful conservation of fish such as Poecilia species depend on analysis of genetic signature and relations among fish species and sub species. Information about the genetic fingerprint and structure of Poecilia species needs to increase several times to enable us for conserve these economic fish in the future. Many factors have contributed to the destruction of fish habitats. Polluted water, hydroelectric dams, and other environmental changes have resulted in the eradication of natural stocks. In this study genomic DNA was extracted from fin tissues and using ten decamer oligo-nucleotides as single primers in Polymerase Chain Reaction (PCR), DNA fingerprinting, dendrogram analysis and genetic similarity matrix were estimated, revealing variations between selected ten species of Poecilia. From the analyzed species three groups that found to be $100 \%$ similar are first group of sample 1 and 2 , second group of sample 3,4 , and 6 and third group of sample 7 and 8 . The described approach holds great promise for further analyses and gives support to biodiversity maintenance as well as for conservation of genetic resources.
\end{abstract}

Keywords- Molly, Poecilia, RAPD, Ornamental fish, Genetic diversity

Citation: Prasad M.P., Chikkaswamy B.K. and Shekhar S. (2013) Detection of Genetic Diversity in an Ornamental Mollies Fish Variety (Poecilia species) using RAPD Molecular Markers. International Journal of Molecular Biology, ISSN: 0976-0482 \& E-ISSN: 0976-0490, Volume 4, Issue 1, pp.-77-80.

Copyright: Copyright@2013 Prasad M.P., et al. This is an open-access article distributed under the terms of the Creative Commons Attribution License, which permits unrestricted use, distribution and reproduction in any medium, provided the original author and source are credited.

\section{Introduction}

Totally 1,539 species of fish has been declared as ornamental fish out of which 32 species dominated the trade. All of these are of freshwater origin. In U.S. households, the guppy Poecilia reticula$l a$ and neon tetra Paracheirodon innesi are the most popular ornamental fish. One of the leading cash crops of the United States of America is Ornamental fish production which is approximately US\$ I,000 million market [1]. The report shows that the ornamental fish trade is growing from past two decades and still expanding worth multi-million dollar market [2]. The global import value of ornamental fishes goes up to US\$ 321 million [3], from which US\$21-48 million belong to the marine ornamental fish trade [4]. Poecilia latipinna is native to brackish waters of North America and widely distributed and capable of tolerating a wide range of water conditions. It is a geographically adaptable species [5]. The sailfin molly, Poecilia latipinna, belongs to the family Poecilidae (the livebearers). This group also includes other members as Eastern mosquitofish (Gambusia holbrooki), the guppy (Poecilia reticulata), mollies (Poecilia spp.) and the platys and swordfishes (Xiphophorus spp.); from which the last two groups are general in the aquarium trade. The black molly, Poecilia sphenops is a common aquarium fish native to Mexico and Central America which often interbreeds with the sailfin molly [6].
According to molecular studies, $P$. latipinna and $P$. mexicana are the parental species involved in the hybridization event that gave rise to $P$. formosa [7,8]. Variation in female preference [9], sperm competition [10], sex ratio variation [11], and numerous other factors have been shown to affect the maintenance and evolution of alternative mating strategies [12-15]. In past few decades, molecular markers have evolved themselves and have totally changed our view of nature. In last ten years, advance technologies has supported greatly in determination of population diversity [16]. As the random amplified polymorphic DNA (RAPD) technique uses universal sets of primers, and no preliminary work such as nucleotide sequencing, filter preparation or probe isolation is necessary, it has an advantage over other systems of genetic documentation [16]. Without having prior knowledge of DNA sequences, one can examine the genomic variation by the development of RAPD markers generated by polymerase chain reaction (PCR) [17-20]. The potential use of RAPD in genetic mapping and population genetics has been widely documented for a large variety of organisms, including fish [21-23]. In this study, in order to detect the genetic variability of Poecilia species, some genetic markers were analyzed, through the use of RAPD. The results were extremely useful, not only to characterize Poecilia species but also to give support to the biodiversity maintenance of this species. 


\section{Materials and Methods \\ Sample Collection}

Total ten species and sub-species of Mollies (Poecilia) family Poeciliidae viz. Black; Black dots on white body; White and orange (big); White and Orange (small); Silver; Orange; Dark reddish orange; White; orange and black dots; Red; and Silver with black spots [Fig-1] were collected from local aquarium pet shops, Bangalore.

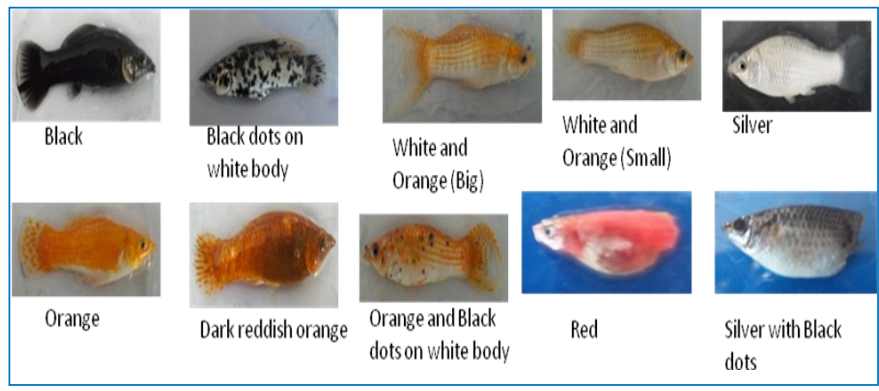

Fig. 1- Fish species

\section{DNA Extraction}

Genomic DNA was extracted from fin tissues according to the method described by Islam and Alam [24]. In brief, approximately $30 \mathrm{mg}$ of fin tissues was cut into small pieces and taken into $1.5 \mathrm{ml}$ microfuge tube. The fin tissue was digested with proteinase- $\mathrm{K}$ in extraction buffer (100 mM Tris, $10 \mathrm{mM}$ EDTA and $250 \mathrm{mM} \mathrm{NaCl}, \mathrm{pH}=8.0$ and $1 \%$ Sodium Dodecyl Sulfate) overnight at $37^{\circ} \mathrm{C}$. DNA was purified once with equal volume of phenol: chloroform: isoamyl alcohol (25:24:1) and once with chloroform: isoamyl alcohol (24:1) and precipitated using 0.8 volumes of chilled isopropanol. The DNA samples were tested qualitatively on $0.8 \%$ agarose gel and quantified by using a Nanodrop spectrophotometer (Thermo Scientific).

\section{PCR Reaction}

A set of 10 decamer oligo-nucleotides was used in this study as single primers in the Polymerase Chain Re-action [Table-1]. The polymerase chain reaction was carried out in final volume of $25 \mu \mathrm{l}$ containing $100 \mathrm{ng}$ DNA, $2 \mathrm{U}$ of Taq DNA polymerase (Chromous Biotech, Bangalore), $2.5 \mathrm{mM} \mathrm{MgCl} 2$ (Chromous Biotech, Bangalore), $2.5 \mathrm{mM}$ each dNTPs (Chromous Biotech, Bangalore) and 100 p mol of primers (Eurofins Genomics, Bangalore). The DNA amplification was performed in the Corbett RG 6000 thermo cycler using the following conditions: complete denaturation $\left(94^{\circ} \mathrm{C}\right.$ for $\left.5 \mathrm{~min}\right), 10$ cycles of amplification $\left(94^{\circ} \mathrm{C}\right.$ for $45 \mathrm{sec}, 35^{\circ} \mathrm{C}$ for $1 \mathrm{~min}$ and $72^{\circ} \mathrm{C}$ for $1.5 \mathrm{~min})$ followed by 30 cycles of amplification $\left(94^{\circ} \mathrm{C}\right.$ for $45 \mathrm{sec}$, $38^{\circ} \mathrm{C}$ for $1 \mathrm{~min}$ and $72^{\circ} \mathrm{C}$ for $1 \mathrm{~min}$ ) and the final elongation step $\left(72^{\circ} \mathrm{C}\right.$ for $\left.5 \mathrm{~min}\right)$.

Table 1- List of primers

\begin{tabular}{|llll|}
\hline Primer & Sequence $\left(5^{\prime} \rightarrow 3^{\prime}\right)$ & Primer & Sequence $\left(5^{\prime} \rightarrow 3^{\prime}\right)$ \\
\hline D-18 & GAG AGC CAA C & T-7 & GGC AGG CTG T \\
D-19 & CTG GGG ACT T & U-10 & ACC TCG GCA C \\
D-20 & ACC CGG TCA C & U-11 & AGA CCC AGA G \\
T-5 & GGG TTT GGC A & U-12 & TCA CCA GCC A \\
T-6 & CAA GGG CAG A & U-13 & GGC TGG TTC C \\
\hline
\end{tabular}

\section{Agarose Gel Electrophoresis of PCR Products}

Total volume of the amplified product $(25 \mu \mathrm{l})$ of each sample was subjected to electrophoresis on $2.0 \%$ agarose gel containing ethidium bromide in 1xTAE buffer at 100V for $1 \mathrm{hrs}$. Finally, the DNA bands were observed on a Gel Doc system and the photographs were captured.

\section{Data Analysis}

The RAPD profiles were analyzed based on the presence or absence of individual RAPD bands. The genetic distance was calculated by the coefficient of Frequency similarity. The matrix of genetic distance was used for grouping the fish samples based on the dendrogram constructed by UPGMA (Unweighed Pair Group Method with Arithmetic averages).

\section{Result and Discussion}

Genomic DNA was extracted from all ten samples and quality was observed in Agarose gel, bands were found to be intact and without RNA contamination. In quantitative analysis, ratio of 260:280 was found to be between 1.0 to 1.97 for all samples [Fig-2]. The RAPD patterns of genomic DNA of Poecilia species by Eurofins Genomics primers D-18, D-19, D-20, T-5, T-6, T-7, U-10, U-11, U-12 and U-13 were analyzed for polymorphism, total two primers gave clear distinctive band pattern as shown [Fig-3]. The band patterns shown in [Fig-3] are developed by primer D-20 and primer T-6 respectively. Primer T-6 does not amplified sample no. 2. Total 54 bands were generated by D-20 and 40 bands by T-6 primer respectively. Approximately $100 \mathrm{bp}, 400 \mathrm{bp}$ and $500 \mathrm{bp}$ bands were found common in all samples except sample no 9 by primer D-20. For primer T-6 approximately $300 \mathrm{bp}$ band was observed in all samples except sample no 2. Band pattern observed for species 9 was different than all other 9 species.

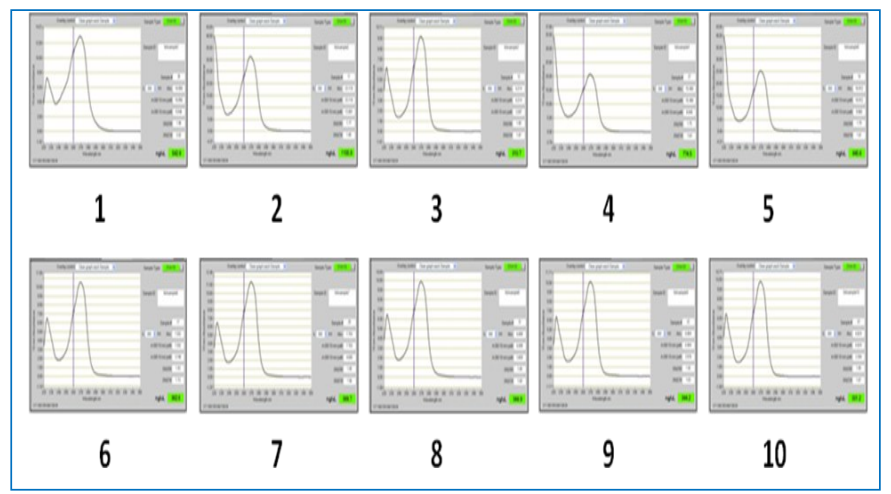

Fig. 2- Quantitative analysis by Nanodrop spectrophotometer 1. Black, 2. Black, dots on white body, 3. White and orange (big), 4. White and Orange (small), 5. Silver, 6. Orange, 7. Dark reddish orange, 8. White orange and black dots, 9. Red, 10. Silver with black spots

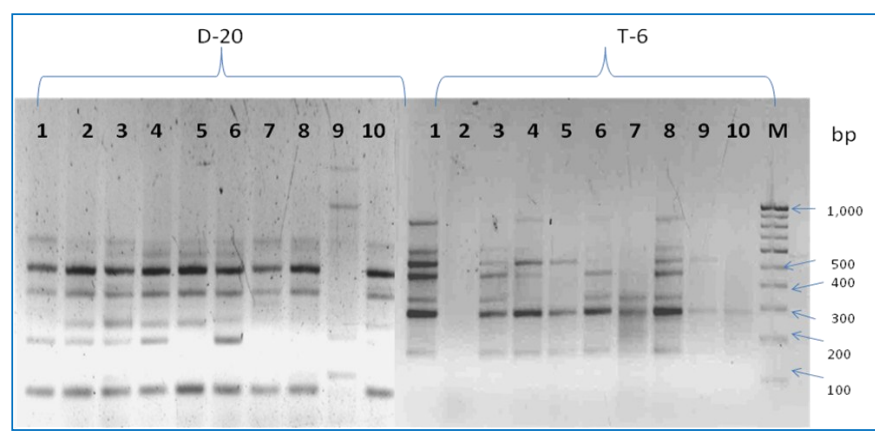

Fig. 3- RAPD patterns from Poecilia species using D-20 and T-6 primer

1. Black, 2. Black, dots on white body, 3. White and orange (big), 4. White and Orange (small), 5. Silver, 6. Orange, 7. Dark reddish orange, 8. White orange and black dots, 9. Red, 10. Silver with black spots, M. DNA marker 
There are some different methods to form clusters like MCLUST which fits a very similar model to fine structure, K-Means which places individuals in the population closest to them and 'Unweighted Pair Group Method with Arithmetic Mean' (UPGMA) which iteratively merges the closest groups. Genetic similarity was calculated using Similarity frequency coefficient and dendrogram was generated to access the genetic relationship among ten selected species [Fig-4]. Dendrogram constructed by cluster analysis of RAPD markers showed that three clusters are 100\% similar for species 1 and 2 (Black and Black dots on white body), for species 3, 4 and 6 (White and orange (big), White and orange (small) and Orange) and species 7 and 8 (Dark reddish orange and White orange and black dots). The aim of a genetic similarity measure is to identify pairs of individuals who are 'closely related' by assigning them higher similarity than those who are distantly related. Similarity matrices can be related to many population genetics methods in a two-stage approach to population genetics by first computing the pairwise similarities, and then perform clustering or other analyses on this summary of the dataset $[25,26]$. There are many possible interpretations of what it means for individuals to be correlated, leading to different matrices being constructed. A simple interpretation of relatedness is the average genetic distance [27]. The similarity index [Table-2] shows that species 1 and 2 are 100\% similar, species 3, 4 and 6 are 100\% similar also species 7 and 8 showed $100 \%$ similarity between them. Maximum diversity has been seen in species 3 and 9, 4 and 9, 6 and 9 with $28.57 \%$ similarity. From the result obtained by Similarity index, it has seen that species 9 is different from rest of the species and could assign different genus to it.

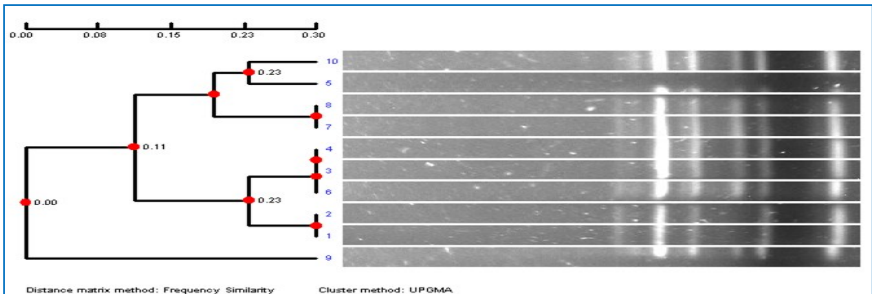

Fig. 4- Dendrogram showing genetic relationship among ten selected species by primer D-20

Dendrogram analysis for primer $D-20$

Table 2- Genetic similarity index of ten species based on RAPD markers

\begin{tabular}{|lccccccccccc|} 
& $\mathbf{1}$ & $\mathbf{2}$ & $\mathbf{3}$ & $\mathbf{4}$ & $\mathbf{5}$ & $\mathbf{6}$ & $\mathbf{7}$ & $\mathbf{8}$ & $\mathbf{9}$ & $\mathbf{1 0}$ \\
\hline 1 & 100 & & & & & & & & & \\
2 & 100 & 100 & & & & & & & & \\
3 & 85.71 & 85.71 & 100 & & & & & & & \\
4 & 85.71 & 85.71 & 100 & 100 & & & & & & \\
5 & 71.43 & 71.43 & 85.71 & 85.71 & 100 & & & & & \\
6 & 85.71 & 85.71 & 100 & 100 & 85.71 & 100 & & & & \\
7 & 42.86 & 42.86 & 57.14 & 57.14 & 71.43 & 57.14 & 100 & & & \\
8 & 42.86 & 42.86 & 57.14 & 57.14 & 71.43 & 57.14 & 100 & 100 & & \\
9 & 42.86 & 42.86 & 28.57 & 28.57 & 42.86 & 28.57 & 42.86 & 42.86 & 100 & \\
10 & 57.14 & 57.14 & 71.43 & 71.43 & 85.71 & 71.43 & 85.71 & 85.71 & 57.14 & 100 \\
\hline
\end{tabular}

\section{Conclusion}

The RAPD profiles in the present study displayed a high degree of polymorphism. This confirms the suitability of RAPD markers for discrimination of Poecilia species. It would be instructional to continue the genetic studies in coming years, including analyses of individuals from other localities and at different times along the year. It is important to mention the fact that data results from RAPD assays can be extended to further dissect traits in a more refined way to exactly knowledge on specific genes and genetic pathways using other molecular methodologies. There is also the opportunity and need to study sequences of specific polymorphic bands, to determine the genes detected by RAPD experiments. Further studies with other molecular methodologies are essential to clarify and confirm genetic relationships among fish species depicted using RAPD.

\section{References}

[1] Frank A., Chapman S.A., Fitz-Coy E.M., Thunberg C.M. and Adams (2007) Journal of the World Aquaculture Society, 28(1), 1-10.

[2] Cheong L. (1996) Revue Scientifique et Technique de l'Office International des Epizoonties, 15, 445-481.

[3] Dawes J., Chao L.N., Petry P., Prang G., Sonneschien L. and Tlusty M. (2001) Conservation and Management of Ornamental Fish Resources of the Rio Negro Basin, Amazonia, BrazilProject Piaba. EDUA, Manaus, Brazil, 100-121.

[4] Wood E. (2001) Marine Conservation Society, Ross-on-Wye, UK, 80.

[5] Al-Akel A.S., AL-Misned H.F., Al-Kahemal K.A., Al-Ghanim Z., Ahmad and Annazri H. (2010) Pak. J. Zool., 42, 169-176.

[6] Shipp R.L. (1986) Guide to Fishes of the Gulf of Mexico, 20th Century Printing, Co. Mobile, Alabama, 256.

[7] Avise J.C., Trexler J.C., Travis J. and Nelson W. (1991) Evolution, 45, 1530-1533.

[8] Schartl M., Wilde B., Schlupp I. and Parzefall J. (1995) Evolution, 49, 827-835.

[9] Rios-Cardenas O., Tudorandm S.R., Morris M. (2007) Anim. Behav., 74, 633-640.

[10]Aspbury A.S. (2007) Behav. Ecol., 18, 776-780.

[11]Magellan K. and Magurran A.E. (2007) Anim. Behav., 74, 15451550.

[12]Hankinson S.J. and Ptacek M.B. (2007) Ethology, 113, 802812.

[13]Hurtado G.J.L. and Uy J.A.C. (2009) Anim. Behav., 77, 11871194.

[14]Plath M., Makowicz A.M., Schlupp I. and Tobler M. (2007) Behav. Ecol., 18, 680-688.

[15]Ptacek M.B., Childress M.J. and Kittell M.M. (2005) Anim. Behav., 70, 1339-1348.

[16]Bahy A.A., Tian-Hua H., Da-Nian Q. and Xiao-Mei W. (2004) Reviews in Fish Biology and Fisheries, 14, 443-453.

[17]Williams S.G.K., Hanafey M.K., Rafalski J.A. and Tingey S.V. (1993) Methods Enzymol., 218, 704-740.

[18]Williams S.G.K., Kubelik A.R., Livak K.J., Rafalski J.A. and Tingey S.V. (1990) Nucleic Acids Res., 18, 6531-6535.

[19]Welsh S. and McClelland M. (1990) Nucleic Acids Res., 18, 7213-7218.

[20]Hadrys H., Balick M. and Schierwater B. (1992) Mol. Ecol., 1, 55-63.

[21]Dergam J.A., Susuki H.I., Shibata O.A., Duboc L.F., Júlio Jr. H.F., Giuliano-Caetano L. and Black W.C. (1998) Genet. Mol. Biol., 21, 493-496.

[22]Nadig S.G., Lee K.L. and Adams S.M. (1998) Aquat Toxicol, 43, 
163-178.

[23]Liu Z.J., Li P., Argue B.J. and Dunham R.A. (1999) Aquaculture, 174, 59-68.

[24]Islam M.S. and Alam M.S. (2004) Journal Applied Ichthyology, 20, 407-412.

[25]Biswas S., Scheinfeldt L.B. and Akey J.M. (2009) Am. J. Hum. Genet., 15, 641-650.

[26]Gao X. and Starmer J. (2007) BMC Genetics, 25-34.

[27]McVean G. (2009) PLoS Genetics, 5(10), e1000686. 